\title{
THYMIC ATROPHY AND FUNGAL VIRULENCE DURING EXPERIMENTAL PARACOCCIDIOIDOMYCOSIS
}

\author{
Vânia Nieto Brito*; Paula Cristina de Souza Souto; Jacy Gameiro; Maria Alice Cruz-Höfling; Liana Verinaud \\ Instituto de Biologia, Universidade Estadual de Campinas, Campinas, SP, Brasil.
}

This paper corresponds to an "extended abstract" selected for oral presentation in the $22^{\text {nd }}$ Brazilian Congress of Microbiology, held in Florianópolis, SC, Brazil, in November 17-20, 2003

\begin{abstract}
The immunosuppression observed in systemic mycosis can be related to primary lymphoid organs damage. Thus, our laboratory has studied the effects of the Paracoccidioides brasiliensis infection on the thymus of mice. Here, thymuses of susceptible and resistant mice were evaluated after inoculation with highly and slightly virulent isolates of the fungus. All groups presented thymic atrophy, loss of corticomedullary delimitation and increase of apoptotic index. However, mice inoculated with high virulent strain showed earlier and stronger alterations suggesting that thymic atrophy can be directly related to the fungal virulence and to the immunosuppression.
\end{abstract}

Key words: Paracoccidioides brasiliensis, thymus, fungal virulence.

\section{INTRODUCTION}

P. brasiliensis $(\mathrm{Pb})$ infects human beings causing a systemic mycosis called paracoccidioidomycosis with elevated incidence in Brazil (2). Considering the tropism of this fungus by lymphoid tissues $(2,3)$, we have studied its action on the thymus in experimental models. In BALB/c mice, we observed that a virulent isolate of $\mathrm{Pb}$ is able to invade the thymic microenvironment inducing severe atrophy, depletion of the cortical layer, loss of the corticomedullary delimitation, and medullary and subcapsular inflammatory infiltrate (1). Also, an increase in programmed cell death (PCD) by apoptosis and autophagy was observed (6). In this work, we evaluated thymic alterations induced by highly and slightly virulent isolates of $\mathrm{Pb}$ in susceptible (B10.A) and resistant mice (A/J).

\section{MATERIALS AND METHODS}

\section{Experimental Design}

$\mathrm{A} / \mathrm{J}$ and B10.A male mice from CEMIB/UNICAMP were intraperitoneally inoculated with $5 \times 10^{6}$ yeasts of $\mathrm{Pb}$ (highly $\mathrm{Pb} 18$ or slight $\mathrm{Pb} 265$ strain) or sterile phosphate buffered saline (control). Lots of 5 mice were weighted and sacrificed at 1,3,5, 7 and 14 days post-infection (pi). Thymuses were collected, weighted, fixed in $10 \%$ buffered formalin and routinely processed for histopathological analysis. One thymic lobe was homogenized in fetal calf serum-supplemented RPMI 1640 medium for total cell number evaluation.

\section{Immunohistochemistry}

Detection of $P b$ in thymus was performed by conventional immunhistochemistry (1). PCD was detected by TUNEL technique (Boehringer, Germany) according to the manufacture's instructions.

\section{Statistical Analysis}

Bonferroni's multiple comparison test was used. The probability level of $p<0.05$ was considered significant.

\section{RESULTS}

All groups studied presented reduction in thymic index since 1 day pi, peaking at the $3^{\text {rd }}$ day and returning to the usual values

*Corresponding author. Mailing address: Cidade Universitária Zeferino Vaz s/n. Instituto de Biologia. Departamento de Microbiologia e Imunologia. Cidade Universitária. Caixa Postal 6109. 13083-970, Campinas, SP, Brasil. E-mail:vanianb@unicamp.br 
after this period (Fig. 1). It was also observed a decrease in thymic total cell number at 3 days pi independently of mice lineage or fungal strain used (Fig. 2).

Morphological alterations could also be observed in all experimental groups. The principals were: presence of yeasts of $\mathrm{Pb}$; reduction in cortical thickness and cellularity, constituting a starry-sky pattern (Fig. 3A); loss or attenuation of corticomedullary delimitation (Fig. 3B) and augment in the apoptotic levels (Fig. 3C).

Despite of similarities described, some relevant differences were observed. A capsular inflammatory infiltrate with granulocytes and plasma cells was observed, except in B10. A mice infected with $\mathrm{Pb} 265$. This infiltrate was larger and more persistent in Pb18-infected mice (Fig. 3D). Besides, all thymic alterations were earlier and stronger in these mice, which also presented more yeasts for a longer period.

\section{DISCUSSION}

In this work we observed thymic alterations similar to previously detected in $\mathrm{BALB} / \mathrm{c}$ mice that present an intermediate susceptibility to disease (1). Moreover, we noted that the highly virulent isolate $\mathrm{Pb} 18$ is more invasive and persistent in thymus causing earlier and stronger alterations than the slightly virulent $\mathrm{Pb} 265$ strain.

We assume that thymic atrophy occurs due to a direct action of $\mathrm{Pb}$, since all alterations were related to the fungal virulence and its presence in this organ. Such action could be related to toxic mediators released by the fungus itself as observed in other fungal disease $(5,7)$. So, thymic atrophy is, most probably, an additional mechanism of virulence contributing for immune modulation and persistence of the $\mathrm{Pb}$ in the host.

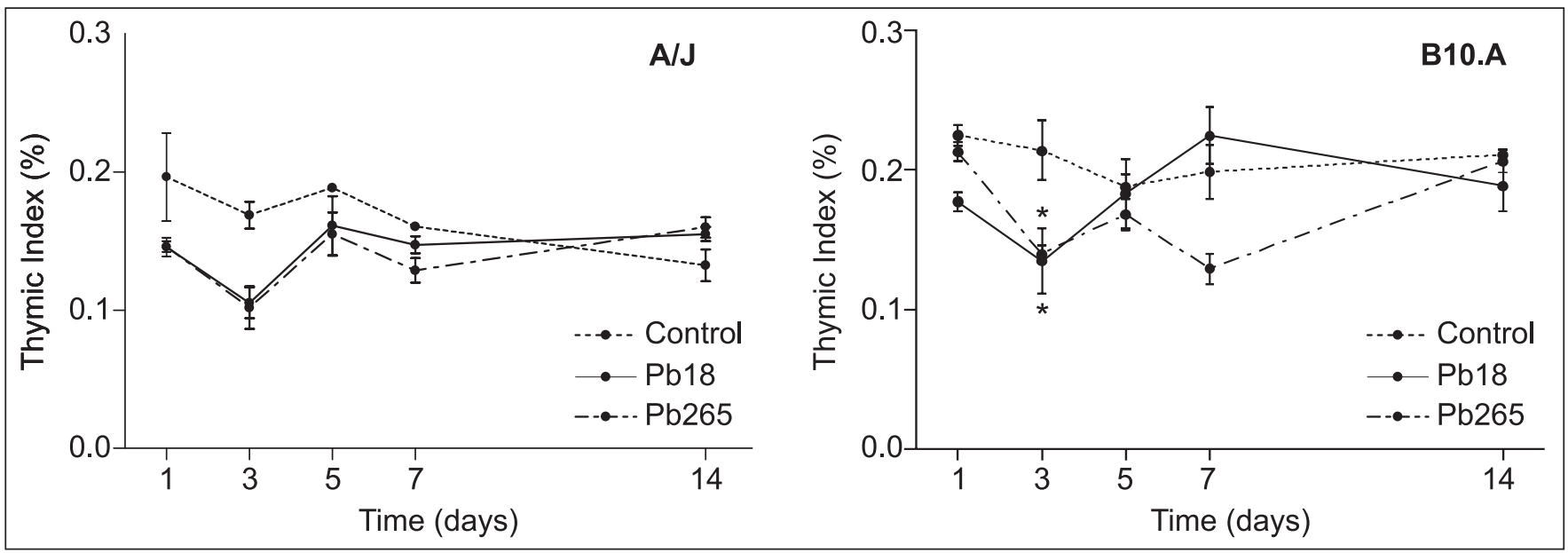

Figure 1. Thymic index. Data are expressed as mean $\pm \operatorname{SEM}(\mathrm{n}=5) .\left({ }^{*} p<0.05\right)$.
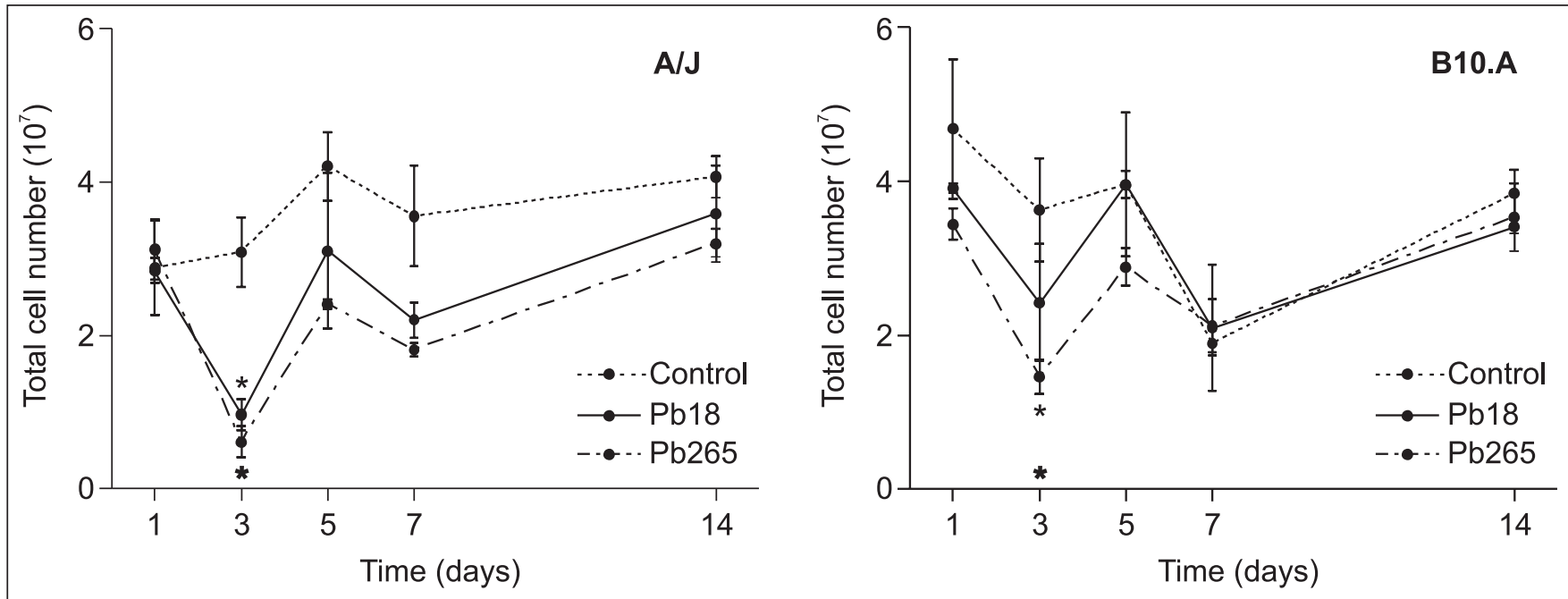

Figure 2. Thymic total cell number. Data are expressed as mean $\pm \operatorname{SEM}(\mathrm{n}=5) .\left({ }^{*} p<0.05\right)$. 


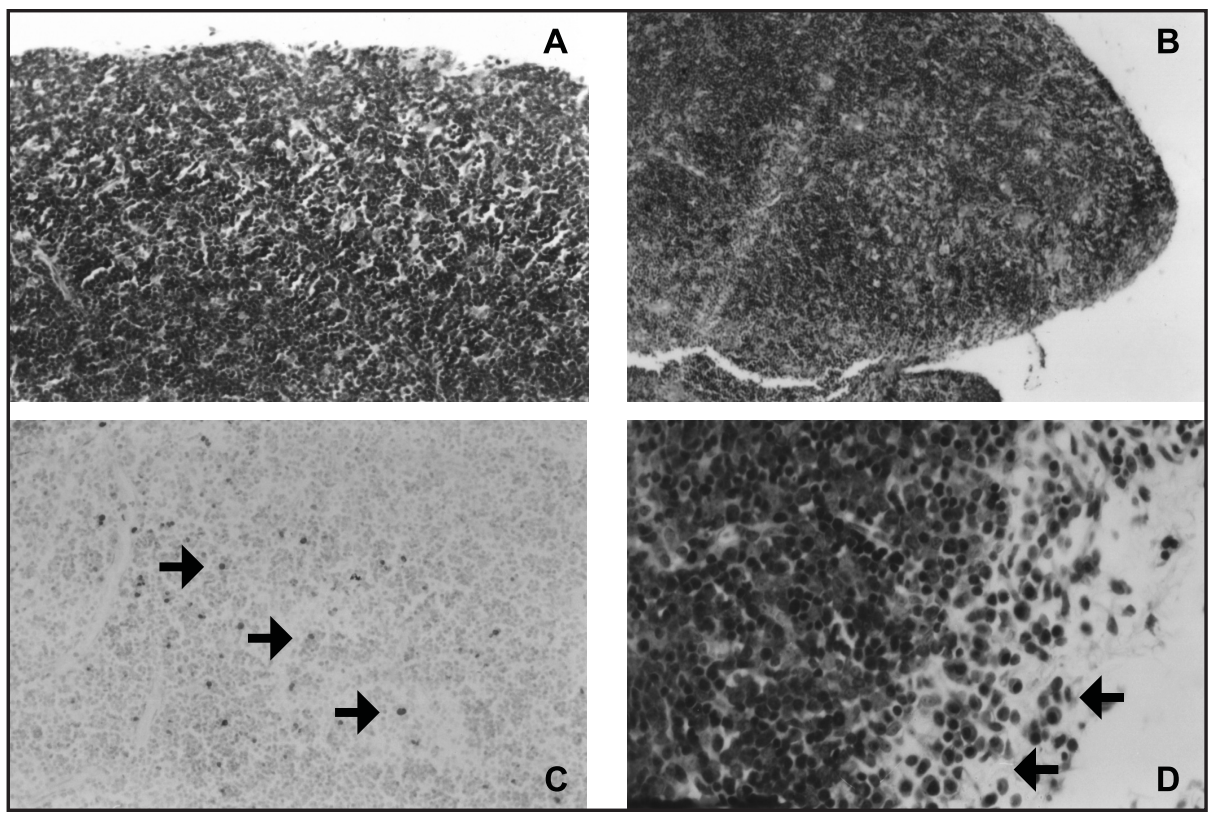

Figure 3. Thymus of mice inoculated with P. brasiliensis.

A. Thymic cortex of a B10.A mouse inoculated with $\mathrm{Pb} 18$ showing a starry-sky pattern. HE. 200x;

B. Thymus from an $\mathrm{A} / \mathrm{J}$ mouse infected with $\mathrm{Pb} 18$, there is not corticomedullary delimitation. HE. 100x;

C. Thymus from an $\mathrm{A} / \mathrm{J}$ mouse inoculated with $\mathrm{Pb} 18$ showing a large number of apoptotic cells. TUNEL counterstained with methyl green. 200x;

D. Thymic capsule of a B10.A mouse inoculated with $\mathrm{Pb} 18$ with an inflammatory infiltrate rich in plasma cells (†). HE. 400x.

\section{ACKNOWLEDGMENTS}

FAEP/UNICAMP (\#858/01), FAPESP (\#03/01891-4) and CAPES supported this work.

\section{RESUMO}

\section{Atrofia tímica e virulência fúngica durante a paracoccidioidomicose experimental}

A imunossupressão observada em micoses sistêmicas pode estar relacionada a danos nos órgãos linfóides primários. Assim, nosso laboratório tem estudado uma possível ação do Paracoccidioides brasiliensis sobre o timo de camundongos. Neste estudo, analisamos o timo de camundongos susceptíveis e resistentes ao fungo utilizando cepas de alta e baixa virulência. Todos os grupos apresentaram atrofia tímica, perda de delimitação corticomedular e aumento da taxa de apoptose. Entretanto, as alterações foram mais precoces e pronunciadas em camundongos inoculados com a cepa virulenta do fungo, sugerindo que a virulência fúngica pode estar diretamente ligada à atrofia tímica e indução de imunossupressão.

Palavras-chave: Paracoccidioides brasiliensis, timo, virulência fúngica.

\section{REFERENCES}

1. Brito, V.N.; Souto, P.C.S.; Ricci, L.C.; Cruz-Hofling, M.A.; Verinaud, L. Thymic invasion and atrophy induced in Paracoccidioides brasiliensis - infected mice. Med. Mycol., 41:1-5, 2003.

2. Brummer, E.; Castaneda, E.; Restrepo, A. Paracoccidioidomycosis: an update. Clin. Microbiol. Rev., 6:89-117, 1993.

3. Franco, M.; Mendes, R.P.; Moscardi-Bacchi, M. Paracoccidioidomycosis. Baillière's Clin. Trop. Med. Comm. Dis., 4:185-220, 1989.

4. Haeryfar, S.M.; Berczi, I. The thymus and the acute phase response Cell. Mol. Biol., 7:145-156, 2001.

5. Islam, Z.; Masahiro, N.; Yoshizawa, T.; Yamauchi, K.; Sakato, N. T2 toxin induces thymic apoptosis in vivo in mice. Toxicol. Appl. Pharmacol., 148:205-214, 1998.

6. Souto, P.C.S.; Brito, V.N.; Gameiro, J.; Cruz-Hofling, M.A.; Verinaud, L. Programmed cell death in thymus during experimental paracoccidioidomycosis, Med. Microbiol. Immunol. In press.

7. Sutton, P.; Newcombe, N.R.; Waring, P.; Müllbacher, A. In vivo immunosuppressive activity of gliotoxin, a metabolite produced by human pathogenic fungi. Infect. Immun., 62:1192-1198, 1994. 